\title{
Solo City Batik Design Security System (SiKemTi Solo) during the Pandemic Covid-19
}

\author{
Jani Kusanti ${ }^{1 *}$, Ramadhian Agus Triono Sudalyo ${ }^{2)}$ \\ 1)2) Surakarta University, Central Java, Indonesia \\ 1)jani_kusanti@yahoo.com, ${ }^{2)}$ ramadhiantriono@yahoo.com
}

Submitted : Sep 17, 2021 | Accepted : Oct 4, 2021 | Published : Oct 12, 2021

\begin{abstract}
Safeguarding copyright on traditional batik works is very important to prevent duplication of Indonesian cultural products. The ease of duplicating, especially in batik designs, causes frequent violations of the design's copyright. Especially with the rise of online commerce today, it is easier for everyone to use other people's products and copy other people's products. This will not happen if there is already a system that can be used to secure the design work. For this reason, it is important to develop methods that can be used to secure traditional batik works, especially Surakarta. Based on these problems, a research was conducted on the application of image watermarking techniques that are resistant to changes generated by image processing in the form of compression. The method used to secure Surakarta batik works is compression using wavelet transformation. The aim is to develop a batik design security system method using the watermarking method. The steps taken started with taking photos of batik designs and the designer's name, photos in the form of images followed by the embedding process using the watermarking method. The watermarking method used is the DWT method. After encryption, identification is carried out to determine the level of errors that occur. The results of testing 323 batik image data in this study obtained an average mse level $=0.00000065$ and an average psnr result $=188.471186102179$. From the results of this study, it was found that the development of methods that can be used to secure batik products by using the watermarking method.
\end{abstract}

Keywords: Enkripsi; Batik; Watermarking, Covid-19; SiKemTi

\section{INTRODUCTION}

The city of Solo is one of the cities of batik craftsmen which is one of the flagship for the Indonesian nation. There are many batik cottage industries in the Solo area (Kusanti \& T.S, 2019), (Kusanti \& Suprapto, 2019), in addition to traditional batik designs, many design developments from traditional batik are combined with modern batik designs. Of the many batik designs they have, the name of the maker does not appear because it belongs to a large company due to the high cost of copyright for one product design, while with the many designs they produce it is deemed impossible for them to register each of their works.

For this reason, it becomes a problem when a design is used by other parties and becomes a trend in the international community. Because the work belongs to a big businessman and does not belong to the craftsman, so the craftsmen do not feel the results of their work.

This is very much felt in the current covid-19 pandemic, the number of online shops has changed trading habits and ways of trading. The ease with which users can copy other people's work makes home craftsmen receive less appreciation. In contrast to well-known designers who have received recognition in the community.

To validate digital works of image ownership, you can apply a blind watermarking scheme as was done (Harahap, Hannan Budiman \& Novamizanti, 2016), (Suheryadi, 2017) and (Febriani, 2016) in their research can prove that the resulting image is still original or has been modified . In addition to using blind watermarking, in a study conducted by (Rosadi, Informasi, \& Sti, 2018) and (Hardianto, Novamizanti, \& Prasasti, 2017) hybrid compression was used to secure medical images. The watermarking method with DCT as done (Saifuddin, Yogyakarta, Mido, \& Yogyakarta, 2020) is used for steganography, as well as research conducted (Ardiansyah, Susilo, \& Erlansari, 2017) used to insert information into the image to secure the image. The results obtained are no difference between the original image and the watermarked image as in the research conducted (Hardianto et al., 2017), (Zulfan \& Muharar, 2016), (Agustina \& Asmara, 2017) and (Ghonge, 2018) . For a home industry

*name of corresponding author 
usually has many batik designs produced, but this design can be duplicated because there is no system that can help to secure the design as an identifier from the initial design owner as in the research conducted (Saputra, Fauziah, \& Hayati, 2020) and (Zulfan \& Muharar, 2016) and (Zhou, Bai, \& Wang, 2015). The existence of a compression system using watermarking allows a product design to be secured as was done in research (Mido et al., 2020), (Suheryadi, 2017) and (Ardiansyah et al., 2017) to be able to find out the owner of the initial design of the product so that Home industry craftsmen will feel the results of their work and can also continue to improve their creative works.

For this reason, it is important to develop a method that can be used for a system that can identify the original owner of a batik design at the Solo batik home industry so that the design works of the craftsmen can be identified by inserting or compressing their names in existing designs that will be uploaded to be marketed online. Like paper money, it will be seen which paper money is real and which is counterfeit as in the study (Zulfan \& Muharar, 2016).

So in this study the author developed a method of a Design Security System with the Watermarking Method for Batik Design Security in Small and Medium Enterprises located at the Solo Batik Home Industry.

\section{LITERATURE REVIEW}

. In the research conducted (Suheryadi, 2017) applying digital watermarking as an authentication and validation tool for digital image ownership. In this study, the validity of the image can be ascertained. Implementing a blind watermark scheme by using a secret key inserted in the least-significant bits (LSB) of the host image invisibly. The results obtained are the watermarked images have a small decrease in quality with the average PSNR and MSE values around 34.08 and 14.62. Research conducted by (Zulfan \& Muharar, 2016) in his research detects image falsification with the copy move technique, the detection feature used is the Ordinal Measure of the Discrete Cosine Transform (OM-DCT) coefficient. Detection begins by dividing the image into blocks of $\mathrm{B} \times \mathrm{B}$ size $(\mathrm{B}=$ 16x16, 32x32 and 64x64) and 2-dimensional DCT is performed on each of these blocks. The distance between the original and the fake image features is calculated by the Ecluidian distance equation and each feature that has a distance less than or equal to the threshold value (T) according to observations will be marked as part of the falsified image.

Research conducted by (Zulfan \& Muharar, 2016) and (Rosadi et al., 2018) performed watermark insertion using the DCT method on digital images. This method was chosen because this method is more robust against image manipulation, especially compression. Watermark embedding is performed at the high frequency of the DCT coefficient. Based on the test, the watermarked image is resistant to image manipulation in the form of compression up to 50\%. The addition of text and color changes results in good watermark image quality, while changing the background, adding filters, and rotating can damage the watermark after the extraction process.

In this study (Handoyo, Setiadi, Rachmawanto, Sari, \& Susanto, 2018) the application of the DCT method to matlab-based text hiding applications. The system development method in this application uses the Discrete Cosine Transform (DCT) method. The final result of the research conducted is the creation of a Steganography application that can insert text messages into a digital image (image). The test results with 50 respondents, the results show that the application has a user friendly display with an average value of 3.90 (good), easy to use the system with an average value of 4.13 (good) and has a good system performance with an average value -average 3.89 (good).

Research conducted by (Febriani, 2016) and (Ito, 2020) in their research implementation of digital watermarking on images using the Least Significant Bit method. Watermarking techniques take advantage of deficiencies in the human senses, namely the eyes and ears. In this research, the watermark is inserted in the image or photo file using the Least Significant Bit (LSB) method. The research conducted by Febriani consists of several stages, namely application planning, application design, application creation, and application testing. At the testing stage, several images were tested and the results did not show any difference between the original image and the watermarked image.

In the research that will be carried out, a text format in the form of the name of the batik design maker will be used which will be inserted into the batik design (photos of batik designs), the method used in this research is Discrete Wavelet Transform (DWT). 


\section{METHOD}

The method used in this study is shown in Fig. 1

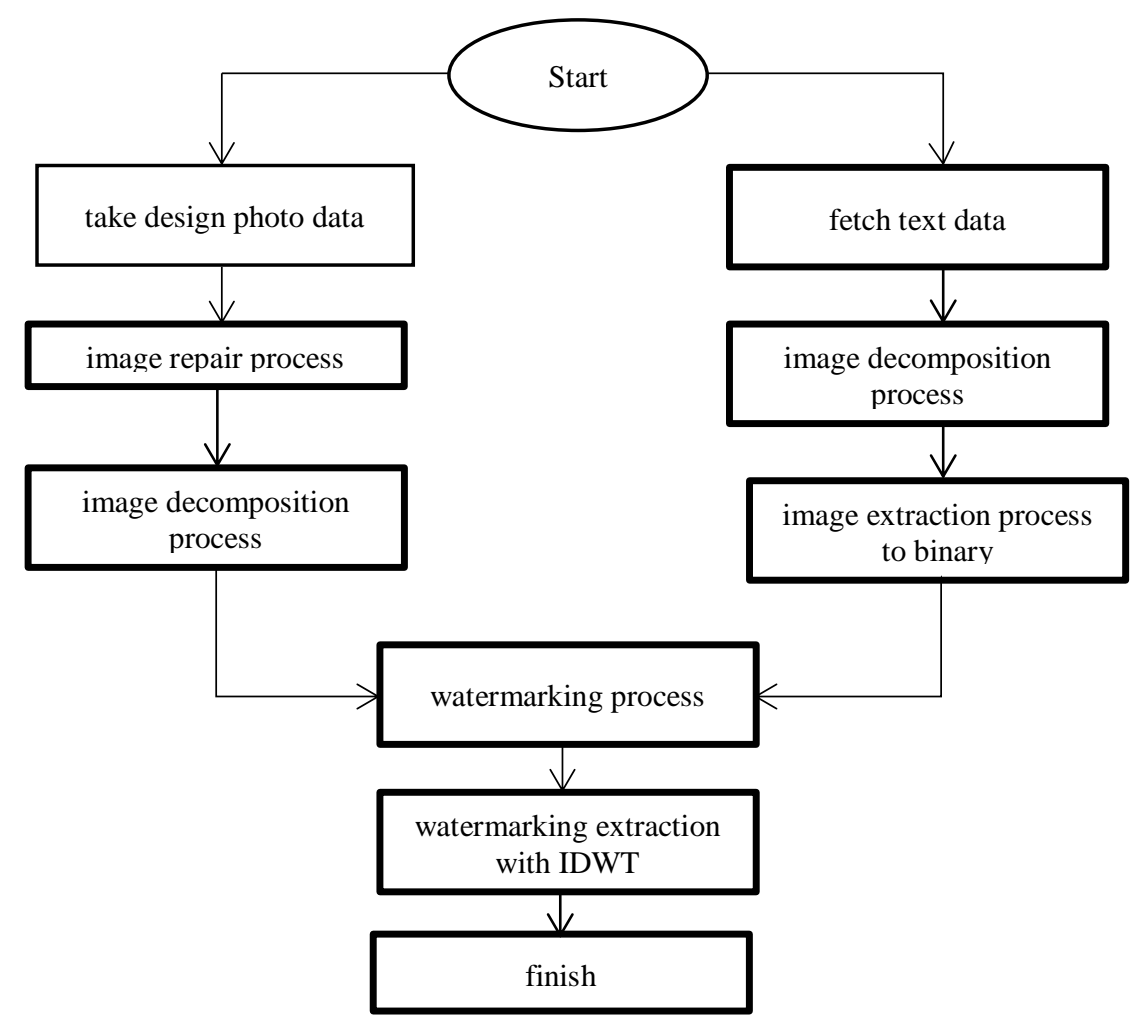

Fig. 1 Research stages

From Fig. 1 the steps can be explained as follows:

1) Retrieve Image Data

Selection of batik design image by selecting the design image used in the form of .jpg. as shown in Fig. 2.

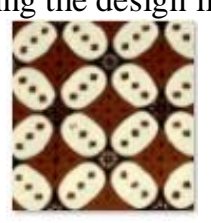

Fig. 2 Kawung_001.jpg

2) The processed image is processed with an image improvement process Image repair is done with grayscale, the results are as shown in Fig. 3.

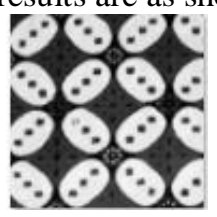

Fig. 3 image repair process

3) Image decomposition process, using wavelet transform haar the results are shown in Fig. 4.

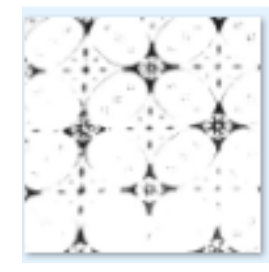

Fig. 4 The result of the decomposition process

This stage is the first step that must be done to be able to insert a watermark into the image.

*name of corresponding author 
4) In Fig. 4 the input image is assumed to be CAj. The Lo_D block represents the lowpass filter, while the Hi_D represents the highpass_filter. The results of the decomposition stage are shown in Fig. 5.

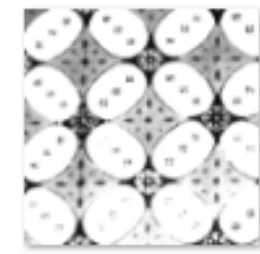

Fig. 5 stage 1 results

which is shown in Fig. 5 in the form of sub-bands consisting of LL (cA), LH (cH), HL (cV), and HH (cD)

5) The LL sub band represents the part of the coefficient obtained through the Low pass filter process followed by Low pass, as shown in Sub band LL Fig. 6.

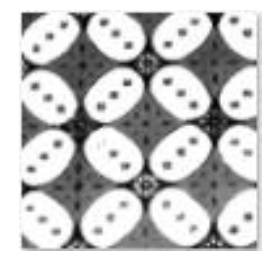

Fig. 6 The results of the Low pass filter process are followed by Low pass

The image in Fig. These 6 sections are similar and are a smoother version of the original image so that the coefficients in the LL section are often referred to as the approximation component (A3).

6) 6) LH (D2) states the part of the coefficient obtained through the Low pass filter process then followed by the High pass. The coefficients in this section represent edge audio in the horizontal direction (D1). The HL section states the portion obtained through the High pass (D3) filter process then followed by the Low pass. The coefficients in this section represent edge audio in the vertical $(\mathrm{cV})$ direction. $\mathrm{HH}$ represents a process that begins with a High pass filter and continues with a High pass, and shows the edge image in the diagonal direction $(\mathrm{cD})$. The three components $\mathrm{LH}, \mathrm{HL}$, and $\mathrm{HH}$ are also called detail components. In this study, after the decomposition process has been carried out, one sub-band is selected from the four sub-bands formed from the original image. The selected sub-band is the sub-band in the low frequency part of LL, which is the approximation coefficient (A3). The selected sub-band (LL) serves as a place for the watermark image insertion process, as shown in Fig. 7.

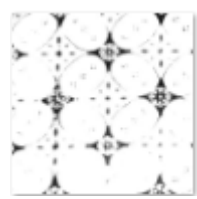

Fig. 7 Sub-band part of the watermark embedding process

The watermark image is selected from one of the sub-bands of the 4 formed sub-bands, which is selected in the sub-band section of the approximation coefficient on the watermark image.

7) Selection of watermark image resolution must be smaller than the original image resolution. In this study, the watermark image or the image to be inserted is $100 \mathrm{~Kb}$ in size, shown in Fig. 8

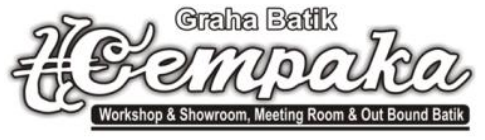

Fig. 8 Inserted logo

8) Decomposition of averages and reductions (differences) plays an important role in understanding the wavelet transform. The following is the formula for decomposition of averaging and subtraction on a onedimensional image with dimensions, shown in Fig. 9.

\begin{tabular}{|l|l|l|l|l|l|l|l|}
37 & 35 & 28 & 28 & 58 & 18 & 21 & 15 \\
\hline
\end{tabular}

Fig. 9 Example of 1-dimensional image

Average is done by calculating the average value of 2 pairs of data with the formula shown in Equation (1):

$$
p=\frac{x+y}{2}
$$

*name of corresponding author 
While the subtraction is carried out with the indicated in Equation (2):

$$
p=\frac{x-y}{2}
$$

The results of the alignment process for the image above can be shown in Equation (3):

$$
\begin{array}{llll}
\frac{37 \quad 35}{36} & \frac{28 \quad 28}{28} & \frac{58 \quad 18}{38} & \frac{21 \quad 15}{18}
\end{array}
$$

While the results of the reduction process with those shown in Equation (4):

$$
\begin{array}{llll}
\frac{37 \quad 35}{1} & \frac{28 \quad 28}{0} & \frac{58 \quad 18}{20} & \frac{21 \quad 15}{3}
\end{array}
$$

While the results of the alignment and reduction decomposition process to the original image above can be shown in Fig. 10:

\begin{tabular}{|l|l|l|l|l|l|l|l|}
\hline 36 & 28 & 38 & 18 & 1 & 0 & 20 & 3 \\
\hline
\end{tabular}

Fig. 10 The results of the smoothing and subtraction transformation process of two images (previous)

. The decomposition process carried out above is only 1 time ( 1 level). Fig. 10 shows the full transformation process and stops after only 1 pixel remains

\begin{tabular}{l}
\begin{tabular}{|l|l|l|l|l|l|l|l|}
\hline 37 & 35 & 28 & 28 & 58 & 18 & 21 & 15 \\
\hline 36 & 28 & 38 & 18 & 1 & 0 & 20 & 3 \\
\hline
\end{tabular} \\
\begin{tabular}{|l|l|l|l|l|l|}
\hline 32 & 28 & 4 & 10 & \\
\hline 30 & 2 &
\end{tabular} \\
\hline
\end{tabular}

Fig. 11 Smoothing and subtraction process with full decomposition (3 levels)

At each level, the decomposition process is only carried out on the results of the smoothing process. The result of the decomposition process is a combination of the results of the smoothing process with all the results of the reduction process. The image of the full decomposition above can be shown in Fig. 12:

\begin{tabular}{|l|l|l|l|l|l|l|l|}
\hline 30 & 2 & 4 & 10 & 1 & 0 & 20 & 3 \\
\hline
\end{tabular}

Fig. 12 Full decomposition process results

In an image of size $2 \mathrm{n}$, it takes $\mathrm{n}$ levels to perform a full decomposition, so it can be said that the complexity of the smoothing and subtraction decomposition is 0 (n). For a 2-dimensional image, the smoothing and subtraction decomposition is the same as the process for the 1-dimensional image above. It's just that the decomposition process is carried out in 2 stages, namely the first stage of the decomposition process is carried out on all rows, then the second stage of the image resulting from the first stage is the decomposition process in the direction of the column. Fig. 13 is an example of a 2dimensional decomposition result

\begin{tabular}{|l|l|l|l|}
\hline 10 & 10 & 20 & 20 \\
\hline 10 & 10 & 20 & 20 \\
\hline 50 & 50 & 30 & 30 \\
\hline 50 & 50 & 30 & 30 \\
\hline
\end{tabular}

(a)

\begin{tabular}{|l|l|l|l|}
\hline 10 & 20 & 0 & 0 \\
\hline 10 & 20 & 0 & 0 \\
\hline 50 & 30 & 0 & 0 \\
\hline 50 & 30 & 0 & 0 \\
\hline
\end{tabular}

(b)

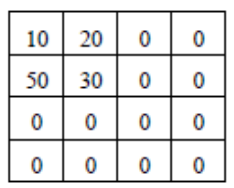

(c)

Fig. 13 The results of smoothing and subtraction decomposition on a 2-dimensional image.

(a) original image (b) decomposition result in row direction (c) decomposition result in column direction (decomposition result image)

\section{Watermark Extraction with IDWT}

In the watermark extraction process, the steps taken are to transform back the coefficients of the original photo image that has been inserted with the watermark. After the process of inserting the approximation

*name of corresponding author 
coefficients from the watermark into the approximation coefficients of the original photo image, the next step is to transform back the coefficients from the original photo image that has been watermarked using the inverse DWT or called IDWT. The result is shown in Fig. 14

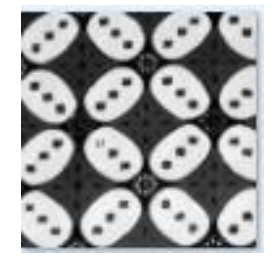

Fig. 14 IDWT Results

The results of testing the 323 image data used can be shown in Table 1

Table 1

Average test results on 323 test data

\begin{tabular}{cccc}
\hline $\begin{array}{c}\text { MSE result } \\
\text { Embedding }\end{array}$ & $\begin{array}{c}\text { PSNR result } \\
\text { Embedding }\end{array}$ & $\begin{array}{c}\text { MSE reslt } \\
\text { Extraction }\end{array}$ & $\begin{array}{c}\text { PSNR result } \\
\text { Extraction }\end{array}$ \\
\hline $6,5283 \mathrm{E}-09$ & 187,606 & 4,609079 & 41,77279 \\
\hline
\end{tabular}

RESULT

The test results of 323 image data were tested twice, both after embedding and after extraction, this was done to see if the image changed to the original image. The results of the embedding process after the identification process obtained the level of similarity with the initial image mse value (mean square error) of 0.00000065 , which means the smaller the error rate, the greater the level of similarity with the original image. This result is also strengthened by testing using the embedding psnr (Peak Signal-to-Noise Ratio) of $187.606 \mathrm{~dB}$, which means that if the psnr value is below $30 \mathrm{~dB}$, the similarity level is lower, and if it is above $30 \mathrm{~dB}$, it shows a high level of similarity with the original image. The results of the testing process after extraction and identification are carried out, the level of similarity with the initial image is obtained, the mse value (mean square error) is 0.00000046 , which means that the smaller the error rate, the greater the level of similarity with the original image. This result is also strengthened by testing using psnr (Peak Signal-to-Noise Ratio) embedding results of $41.772 \mathrm{~dB}$, which means that it shows a high level of similarity with the original image.

\section{DISCUSSIONS}

The results of the tests in this study were tested to determine the level of validation when identification was made on the IDWT image. This is important to do so that when the identification test is carried out on the batik image there is no decrease in the validation results.

The results of the identification test with 323 test data and a comparison of the test with the results of tests carried out with image test data without watermarking yields $93 \%$, while the results of identification tests carried out with data after watermarking has a validation level of $95 \%$.

\section{CONCLUSION}

From the research results obtained by developing a batik image security method using watermarking, it is needed to identify the owner of the batik produced, so that it can secure the product it produces. It is evident from the embedding process and the extraction of the image results that are carried out when used for batik identification the results do not affect the identification process, this is evidenced by the results of the embedding process the mse value (mean square error) of 0.00000065 which means a high level of similarity with the original image and testing using psnr (Peak Signal-to-Noise Ratio) of $187.606 \mathrm{~dB}$, which means it shows a high level of similarity with the original image. The results of the testing process after the extraction of the mse value (mean square error) of 0.00000046 which means that the level of similarity is high with the original image and the results using the psnr (Peak Signal-to-Noise Ratio) of $41.772 \mathrm{~dB}$, which means that it shows a high level of similarity with the image original. Thus, it can be concluded that for online trading, it is better to use batik images that have gone through the embedding process, so that when the image is used by someone else, the original owner of the product can be identified by extraction. This can secure the owner of the design without destroying the image itself.

\section{REFERENCES}

*name of corresponding author 
Agustina, R., \& Asmara, R. A. (2017). Penyisipan Watermark Menggunakan Metode Discrete Cosine Transform Pada Citra Digital. Jurnal Informatika Polinema, 2(1), 29. https://doi.org/10.33795/jip.v2i1.51

Ardiansyah, H., Susilo, B., \& Erlansari, A. (2017). Penerapan Metode Dct ( Discrete Cosine Transform ) Pada Aplikasi Penyembunyian. Jurnal Rekursif, 5(1), 66-74.

Febriani, S. R. (2016). Implementasi Digital Watermarking. 21(3), 8-18.

Ghonge, S. (2018). Classification of Motorcyclists without Helmet via Daubechies Wavelet Transform and SVM. Helix, 8(5), 3998-4001. https://doi.org/10.29042/2018-3998-4001

Handoyo, A. E., Setiadi, D. R. I. M., Rachmawanto, E. H., Sari, C. A., \& Susanto, A. (2018). Teknik Penyembunyian dan Enkripsi Pesan pada Citra Digital dengan Kombinasi Metode LSB dan RSA. Jurnal Teknologi Dan Sistem Komputer, 6(1), 37-43. https://doi.org/10.14710/jtsiskom.6.1.2018.37-43

Harahap, Hannan Budiman, G., \& Novamizanti, L. (2016). Implementasi Teknik Watermarking menggunakan FFT dan Spread Spectrum Watermark pada Data Audio Digital. Jurnal Elkomika, 4(1). https://doi.org/10.26760/elkomika.v4i1.98

Hardianto, R. H., Novamizanti, L., \& Prasasti, A. L. (2017). Implementasi dan Analisis Kompresi Hybrid pada Citra Medis Digital Hasil Rontgen Kanker Payudara. Jurnal Terapan Teknologi Informasi, 1(2), 143-153. https://doi.org/10.21460/jutei.2017.12.39

Ito, I. (2020). A new pseudo-spectral method using the discrete cosine transform. Journal of Imaging, 6(4). https://doi.org/10.3390/jimaging6040015

Kusanti, J., \& Suprapto, A. (2019). Combination of Otsu and Canny Method to Identify the Characteristics of Solo Batik as Surakarta Traditional Batik. In 2019 2nd International Conference of Computer and Informatics Engineering (IC2IE). https://doi.org/10.1109/IC2IE47452.2019.8940884

Kusanti, J., \& T.S, R. A. (2019). Application System for Identification of Surakarta Traditional Batik Images (SABATARA). In SinkrOn (Vol. 4). https://doi.org/10.33395/sinkron.v4i1.10202

Mido, A. R., Magister, S., Informasi, T., Yogyakarta, U. T., Discrete, M., Transformation, C., ... Error, M. S. (2020). Perancangan Aplikasi Steganografi Menggunakan Metode Discrete Cosine Transformation berbasis $\begin{array}{llll}\text { Android. } & \text { (February), 25-36. } & \text { Retrieved }\end{array}$ http://ojs.stmikbanjarbaru.ac.id/index.php/progresif/article/download/425/344

Rosadi, A., Informasi, S., \& Sti, S. J. (2018). Aplikasi Kompresi Citra Dengan Matlab R2015a Menggunakan Metode Discrete Cosine Transform (DCT) dan Kuantisasi. Jurnal Ilmiah Komputasi, 17(1), 21-34. https://doi.org/10.32409/jikstik.17.1.2339

Saifuddin, S., Yogyakarta, U. T., Mido, A. R., \& Yogyakarta, U. T. (2020). Perancangan Aplikasi Steganografi Menggunakan Metode Discrete Cosine Transformation berbasis Android Perancangan Aplikasi Steganografi Menggunakan Metode Discrete Cosine Transformation berbasis Android. (February).

Saputra, T. I., Fauziah, F., \& Hayati, N. (2020). Implementasi Discrete Wavelet Transform Pada Aplikasi Kompresi Citra Medis. Jurnal Infomedia:Teknik Informatika, Multimedia \& Jaringan, 4(2), 101-107. https://doi.org/10.30811/JIM.V4I2.1574

Suheryadi, A. (2017). Penerapan Digital Watermark Sebagai Validasi Keabsahan Gambar Digital Dengan Skema Blind Watermark. JTT (Jurnal Teknologi Terapan), 3(2), 1-6. https://doi.org/10.31884/jtt.v3i2.54

Zhou, X., Bai, Y., \& Wang, C. (2015). Image compression based on discrete cosine transform and multistage vector quantization. International Journal of Multimedia and Ubiquitous Engineering, 10(6), 347-356. https://doi.org/10.14257/ijmue.2015.10.6.33

Zulfan, F., \& Muharar, A. dan R. (2016). Deteksi Pemalsuan Citra dengan Teknik Copy-Move Menggunakan Metode Ordinal Measure dari Koefisien Discrete Cosine Transform. Jurnal Nasional Teknik Elektro, 5(2). https://doi.org/10.20449/jnte.v5i2.230

*name of corresponding author 